INTERNATIONAL JOURNAL OF RESEARCHES IN BIOSCIENCES, AGRICULTURE \& TECHNOLOGY ( ) VISHWASHANTI MULTIPURPOSE SOCIETY (Global Peace Multipurpose Society) R. No. MH-659/13(N) www.vmsindia.org

\title{
CHANGES IN CHEMICAL AND BIOCHEMICAL PARAMETERS OF CHICKPEA (CICER ARIETINUM L.) SPRAYED WITH PUTRESCINE AND NAPHTHALENE ACETIC ACID
}

\author{
Deotale R. D., Jaybhaye V. R., Patil S.R, Kalamkar V. and Kamdi S.R. \\ College of Agriculture, Nagpur (M.S) India \\ Email: rajeshdeotale11@gmail.com
}

\begin{abstract}
Field experiment was conducted during the rabi seasons of 2015-16 at shankarnagar farm of Agril. Botany Section, College of Agriculture, Nagpur to study the effect of foliar application of different concentrations of putrescine $(25,50,75,100,125$ and $150 \mathrm{ppm})$ and naphthalene acetic acid $(25$ and 50 $\mathrm{ppm}$ ) either individually or in combination at one physiological stages (vegetative, 30-35 DAS) on chemical, biochemical, yield and yield contributing parameters of chickpea (Cicer arietinum L.). The field experiment was laid out in Randomized Block Design with three replication. The observations were recorded at 25, 45, 65 and 85 DAS. The obtained results showed that $50 \mathrm{ppm}$ NAA plus $100 \mathrm{ppm}$ putrescine significantly improved nitrogen, phosphorus, potassium, chlorophyll content in leaves and protein content in seeds of chickpea. Yield contributing parameters viz., number of pods plant ${ }^{-1}$, weight of 100 seeds and seed yield ha-1 were also significantly enhanced. Application of putrescine and/or NAA at 100 and $50 \mathrm{ppm}$ respectively produced the highest number of pods which resulted in substantially the highest seed yield. Putrescine and NAA increase the seed yield by $25.3 \%$ and $26.0 \%$ ha $^{-1}$ respectively, $^{2}$ while the combination of $50 \mathrm{ppm}$ NAA plus $100 \mathrm{ppm}$ putrescine increased it by $33.2 \%$. But, considering the B : C ratio foliar application of $50 \mathrm{ppm}$ NAA was found most effective treatment having B : C ratio of 5.9 as compared to 5.1 in control.
\end{abstract}

Keywords: Chickpea, Biochemical, Yield parameters, Putrescine, NAA

\section{Introduction:}

Grain legumes are important crop plants for their protein rich seeds that used as a major source of dietary protein for human and livestock consumption. In addition, legumes can be efficiently used for improving soil fertility (Manchanda and Garg, 2008). Chickpea (Cicer arietinum L.) is important pulse crop grown and consumed all over the world, especially in the Afro-Asian countries (Jukanti et al., 2012). Chickpea is the cheapest and readily available source of protein (20.6\%), carbohydrate (61.2\%), (Gupta, 1987), rich in vitamins and minerals and is relatively free from antinutritional factors (Wang et al., 2010). Because of the great importance of chickpea as a cheapest and readily available source of protein food for large population groups, particularly in developing countries, many efforts have been made to improve chickpea productivity (Alvi et al., 2005). Plant growth regulators so far have emerged as "magic chemicals" that could increase agricultural production at an unprecedented rate and help in removing and circumventing many of barriers imposed by genetics and environment. Plant growth regulators when added in small amounts modify the natural growth regulatory system right from seed germination to senescence in several crop plants.

Plant growth regulators play key role in contributing internal mechanisms of plant growth by interacting with key metabolic processes such as, nucleic acid metabolism and protein synthesis. Plant growth regulators are known to enhance the source-sink relationship and stimulate the translocation of photo-assimilates thereby helping in effective flower formation, fruit and seed development and ultimately enhance productivity of the crops. Growth regulators can improve the physiological efficiency including photosynthetic ability and enhance the effective partitioning of accumulates from source and sink in the field crops (Solamani et al., 2001). Plant growth regulators are shown to change leaf resistance by altering stomatal aperture, the rate of photosynthesis could be manipulated through this technology. Putrescine, IBA, IAA, GA, kinetin, phenolics and aliphatic alcohols are reported to increase and stimulate the rate of photosynthesis. The diamine putrescine occurred widely in the higher plants. It was suggested to be involved in a variety of 
growth and developmental processes such as cell division (Bueno and Matilla, 1992), fruit set and growth (Biasi et al., 1991).

NAA (Naphthalene Acetic Acid) is the synthetic auxin with the identical properties to that naturally occurring auxin. It prevents formation of abscission layer and thereby flower drop. It was observed that the growth regulators are involved in the direct transport of assimilates from source to sink (Sharma et al., 1989). NAA is synthetic auxin with identical properties to that of naturally occurring auxin i.e., IAA in plant. Auxin in low concentration promotes cell elongation i.e., growth, but in higher concentration it inhibits the growth. Planofix (NAA) increased number of pods plant $^{-1}$, dry pod yield and 100 seed weight in groundnut (40 and 50 days after sowing) (Singh and Sharma, 1982). Suty (1984) reported that Rhodofix (NAA) at $3.4 \mathrm{~g} \mathrm{ha}^{-1}$ increased the number of pods plant ${ }^{-1}$, seeds pod-1 $^{-1} 100$ seed weight. Upadhyay et al. (1993) sprayed 0, 10, 20, or 30 ppm NAA at bud initiation and pod formation stages of chickpea (Cicer arietinum L.). Maximum number of seeds pod $^{-1}$ and grain yield was obtained when NAA was applied 15 days after emergence stage (Khanzada et al. 2002).

Considering the above aspect the current research work was carried out with the objective to find the influence of putrescine and NAA on chemical, biochemical, yield and yield contributing parameters of chickpea.

\section{Materials and Methods:}

The present investigation was undertaken during the rabi season of 2015-2016. The experiment was laid out in randomized block design with twenty one treatments and three replications at farm of Botany section, College of Agriculture, Nagpur. Plot size of individual treatment was gross 2.10 $\mathrm{m} \times 2.20 \mathrm{~m}$ and net $1.50 \mathrm{~m} \times 2.20 \mathrm{~m}$. Seeds of chickpea variety Jaki-9218 were sown at the rate of $75 \mathrm{~kg} \mathrm{ha}^{-1}$ by dibbling method at spacing of $30 \mathrm{~cm} \mathrm{X} 10 \mathrm{~cm}$ on 10th Nov 2015. Treatments comprised of $\mathrm{T}_{1}$ (control), $\mathrm{T}_{2} \quad$ (25 ppm putrescine), $\mathrm{T}_{3} \quad(50 \mathrm{ppm}$ putrescine), $\mathrm{T}_{4}$ (75 ppm putrescine), $\mathrm{T}_{5}$ (100 ppm putrescine), $\mathrm{T}_{6}$ (125 ppm putrescine), $\mathrm{T}_{7}$ (150 ppm putrescine), $\mathrm{T}_{8}$ (25 ppm NAA),
T9 (50 ppm NAA), T10 (25 ppm NAA +25 ppm putrescine), $\mathrm{T}_{11}$ (25 ppm NAA +50 ppm putrescine), $\mathrm{T}_{12}$ (25 ppm NAA +75 ppm putrescine), $\mathrm{T}_{13}$ (25 ppm NAA +100 ppm putrescine), $\mathrm{T}_{14}$ (25 ppm NAA + 125 ppm putrescine), $\mathrm{T}_{15}$ (25 ppm NAA +150 ppm putrescine), $\mathrm{T}_{16}$ (50 ppm NAA +25 ppm putrescine), $\mathrm{T}_{17}$ (50 ppm NAA +50 ppm putrescine), $\mathrm{T}_{18}$ (50 ppm NAA +75 ppm putrescine), $\mathrm{T}_{19}$ (50 ppm NAA +100 ppm putrescine), $\mathrm{T}_{20}$ (50 ppm NAA + 125 ppm putrescine), $\mathrm{T}_{21}$ (50 ppm NAA +150 ppm putrescine). The foliar application of putrescine and MAA was given at one stages i.e. 30-35 DAS on chickpea. The chemical and biochemical observations viz., Leaf chlorophyll content was estimated by colorimetric method as suggested by Bruinsma, (1982), nitrogen content in leaves was determined by micro-kjeldhal's method as given by Somichi et al. (1972), phosphorus content in leaves was determined by vanadomolybdate yellow colour method as given by Jackson (1967) and potassium content in leaves was determined by flame photometer by di-acid extract method given by Jackson (1967) at 25, 45, 65 and 85 DAS. For estimating protein content in seed (\%), nitrogen content in seed was determined by micro-kjeldhal's method (Somichi et al.,1972) and same was converted into crude protein by multiplying 'N' percentage with factor 6.25. Observations on yield and yield contributing parameters like, number of pods plant ${ }^{-1}$, 100 seed weight and seed yield hectare ${ }^{-1}$ were also recorded. The data collected were subjected to statistical analysis by employing the method for RBD as suggested by Panse and Sukhatme (1954). The F-test was applied to determine the significance of all treatments. Standard error and critical difference at $5 \%$ level of probability was used for comparing treatment differences.

\section{Results And Discussion:}

The chemical and biochemical studies with respect to chlorophyll, $\mathrm{N}, \mathrm{P}, \mathrm{K}$ content in leaves at different stages of observations as well as protein content in seed were estimated and data regarding these parameters have been presented here under. 


\section{Leaf nitrogen content}

Nitrogen is key component in mineral fertilizers and has more influence on plant growth, appearance and fruit production / quality than any other essential elements. Nitrogen is an important constituent of protein and protoplasm and essential for the growth of plants. Its storage leads to chlorosis and stoppage of growth and its presence in moderate doses is essential for plant growth and fruiting. An abundant supply of essential nitrogenous compound is required in each plant cell for normal cell division, growth and respiration. The $\mathrm{N}$ present mostly as protein is constantly moving and under concentration of $\mathrm{N}$ is found in young, tender plant tissues like tips of shoots, buds and new leaves (Jain, 2010).

The data obtained about the nitrogen content in leaves are given in Table- 1 .

Table-1. Effect of putrescine and NAA on leaf nitrogen, phosphorus, potassium content (\%) and chlorophyll content ( $\left.\mathrm{mg} \mathrm{g}^{-1}\right)$ in chickpea

\begin{tabular}{|c|c|c|c|c|c|c|c|c|c|c|c|c|}
\hline \multirow[t]{2}{*}{$\begin{array}{l}\text { Treatments } \\
\text { nitrogen content }(\%)\end{array}$} & \multicolumn{3}{|c|}{ Leaf } & \multicolumn{3}{|c|}{$\begin{array}{c}\text { Leaf phosphorous content } \\
(\%)\end{array}$} & \multicolumn{3}{|c|}{$\begin{array}{l}\text { Leaf potassium content } \\
\qquad(\%)\end{array}$} & \multicolumn{3}{|c|}{$\begin{array}{l}\text { Leaf chlorophyll content } \\
\qquad\left(\mathrm{mg} \mathrm{g}^{-1}\right)\end{array}$} \\
\hline & $\begin{array}{c}45 \\
\text { DAS }\end{array}$ & $\begin{array}{c}65 \\
\text { DAS }\end{array}$ & $\begin{array}{c}85 \\
\text { DAS }\end{array}$ & 45 DAS & 65 DAS & 85 DAS & $\begin{array}{l}45 \\
\text { DAS }\end{array}$ & $\begin{array}{l}65 \\
\text { DAS }\end{array}$ & $\begin{array}{l}85 \\
\text { DAS }\end{array}$ & 45 DAS & 65 DAS & 85 DAS \\
\hline $\mathbf{T}_{1}$ (control) & 1.89 & 2.17 & 2.10 & 0.589 & 0.645 & 0.629 & 0.81 & 1.01 & 0.87 & 1.37 & 1.45 & 1.25 \\
\hline$T_{2}$ (25 ppm putrescine) & 1.96 & 2.26 & 2.13 & 0.602 & 0.664 & 0.654 & 0.85 & 1.05 & 0.91 & 1.42 & 1.5 & 1.49 \\
\hline $\mathrm{T}_{3}(50 \mathrm{ppm}$ putrescine ) & 2.10 & 2.56 & 2.31 & 0.639 & 0.702 & 0.691 & 0.97 & 1.17 & 1.03 & 1.54 & 1.63 & 1.59 \\
\hline $\mathrm{T}_{4}(75 \mathrm{ppm}$ putrescine ) & 2.14 & 2.63 & 2.45 & 0.648 & 0.714 & 0.700 & 1.00 & 1.21 & 1.07 & 1.58 & 1.67 & 1.62 \\
\hline$T_{5}(100$ ppm putrescine ) & 2.55 & 3.32 & 3.18 & 0.709 & 0.805 & 0.776 & 1.32 & 1.54 & 1.41 & 1.87 & 2.04 & 1.93 \\
\hline $\mathrm{T}_{6}(125 \mathrm{ppm}$ putrescine ) & 2.06 & 2.48 & 2.24 & 0.623 & 0.687 & 0.686 & 0.93 & 1.13 & 0.99 & 1.52 & 1.60 & 1.56 \\
\hline $\mathrm{T}_{7}(150 \mathrm{ppm}$ putrescine $)$ & 2.03 & 2.38 & 2.17 & 0.613 & 0.680 & 0.669 & 0.89 & 1.09 & 0.95 & 1.48 & 1.56 & 1.53 \\
\hline$T_{8}$ (25 ppm NAA) & 2.17 & 2.68 & 2.52 & 0.651 & 0.718 & 0.716 & 1.04 & 1.23 & 1.11 & 1.60 & 1.70 & 1.65 \\
\hline $\mathrm{T}_{9}$ (50 ppm NAA) & 2.59 & 3.36 & 3.24 & 0.711 & 0.810 & 0.778 & 1.35 & 1.59 & 1.45 & 1.87 & 2.06 & 1.96 \\
\hline $\begin{array}{l}T_{10}(25 \text { ppm NAA }+25 p p m \\
\text { putrescine })\end{array}$ & 2.31 & 3.05 & 2.80 & 0.686 & 0.764 & 0.749 & 1.21 & 1.39 & 1.29 & 1.76 & 1.89 & 1.81 \\
\hline $\begin{array}{l}T_{11}(25 \text { ppm NAA }+50 \mathrm{ppm} \\
\text { putrescine) }\end{array}$ & 2.38 & 3.15 & 2.94 & 0.693 & 0.777 & 0.760 & 1.24 & 1.42 & 1.33 & 1.78 & 1.93 & 1.83 \\
\hline $\begin{array}{l}T_{12}(25 \text { ppm NAA }+75 p p m \\
\text { putrescine })\end{array}$ & 2.45 & 3.22 & 3.01 & 0.701 & 0.790 & 0.765 & 1.28 & 1.45 & 1.37 & 1.80 & 1.97 & 1.86 \\
\hline $\begin{array}{l}\mathrm{T}_{13}(25 \mathrm{ppm} \mathrm{NAA}+100 \mathrm{ppm} \\
\text { putrescine) }\end{array}$ & 2.52 & 3.29 & 3.08 & 0.706 & 0.799 & 0.772 & 1.29 & 1.49 & 1.39 & 1.83 & 2.00 & 1.90 \\
\hline $\begin{array}{l}\mathrm{T}_{14}(25 \mathrm{ppm} \text { NAA }+125 \mathrm{ppm} \\
\text { putrescine) }\end{array}$ & 2.30 & 2.94 & 2.73 & 0.684 & 0.760 & 0.738 & 1.19 & 1.37 & 1.26 & 1.73 & 1.87 & 1.79 \\
\hline $\begin{array}{l}T_{15}(25 \mathrm{ppm} \text { NAA }+150 \mathrm{ppm} \\
\text { putrescine })\end{array}$ & 2.27 & 2.87 & 2.69 & 0.678 & 0.751 & 0.736 & 1.15 & 1.33 & 1.21 & 1.69 & 1.83 & 1.75 \\
\hline $\begin{array}{l}\mathrm{T}_{16}(50 \mathrm{ppm} \mathrm{NAA}+25 \mathrm{ppm} \\
\text { putrescine ) }\end{array}$ & 2.66 & 3.43 & 3.28 & 0.713 & 0.814 & 0.779 & 1.38 & 1.63 & 1.49 & 1.93 & 2.11 & 2.02 \\
\hline $\begin{array}{l}T_{17}(50 \text { ppm NAA }+50 \mathrm{ppm} \\
\text { putrescine })\end{array}$ & 2.73 & 3.50 & 3.36 & 0.715 & 0.817 & 0.781 & 1.42 & 1.68 & 1.53 & 1.97 & 2.15 & 2.07 \\
\hline $\begin{array}{l}T_{18}(50 \text { ppm NAA }+75 \text { ppm } \\
\text { putrescine) }\end{array}$ & 2.80 & 3.57 & 3.43 & 0.721 & 0.824 & 0.783 & 1.45 & 1.74 & 1.58 & 2.01 & 2.20 & 2.11 \\
\hline $\begin{array}{l}T_{19}(50 \text { ppm NAA }+100 \text { ppm } \\
\text { putrescine })\end{array}$ & 2.87 & 3.71 & 3.56 & 0.723 & 0.829 & 0.785 & 1.46 & 1.79 & 1.64 & 2.04 & 2.24 & 2.15 \\
\hline $\begin{array}{l}\mathrm{T}_{20}(50 \mathrm{ppm} \mathrm{NAA}+125 \mathrm{ppm} \\
\text { putrescine })\end{array}$ & 2.24 & 2.80 & 2.63 & 0.673 & 0.745 & 0.730 & 1.11 & 1.30 & 1.17 & 1.65 & 1.78 & 1.72 \\
\hline $\begin{array}{l}T_{21}(50 \text { ppm NAA }+150 \mathrm{ppm} \\
\text { putrescine ) }\end{array}$ & 2.20 & 2.73 & 2.59 & 0.667 & 0.736 & 0.718 & 1.07 & 1.27 & 1.14 & 1.63 & 1.75 & 1.69 \\
\hline SE (m) \pm & 0.144 & 0.182 & 0.170 & 0.030 & 0.041 & 0.033 & 0.071 & 0.085 & 0.077 & 0.103 & 0.115 & 0.111 \\
\hline CD at $5 \%$ & 0.411 & 0.519 & 0.487 & 0.085 & 0.116 & 0.095 & 0.204 & 0.242 & 0.219 & 0.294 & 0.330 & 0.317 \\
\hline
\end{tabular}


The data recorded found significant variations at all the stages of observations due to the foliar application of different concentrations of putrescine and NAA at 45, 65 and 85 DAS except 25 DAS. At 45 and 85 DAS nitrogen content was significantly more in treatment $\mathrm{T}_{19}(50 \mathrm{ppm}$ NAA +100 ppm putrescine) followed by treatments $\mathrm{T}_{18}$ (50 ppm NAA +75 ppm putrescine), $\mathrm{T}_{17}$ (50 ppm NAA + 50 ppm putrescine), $\mathrm{T}_{16}(50 \mathrm{ppm}$ $\mathrm{NAA}+25 \mathrm{ppm}$ putrescine), T9 (50 ppm NAA), $\mathrm{T}_{5}$ (100 ppm putrescine) and $\mathrm{T}_{13}(25$ ppm NAA + 100 ppm putrescine) in a descending manner when compared with treatment $\mathrm{T}_{1}$ (control). At 65 DAS nitrogen content was significantly maximum in treatment $\mathrm{T}_{19}(50 \mathrm{ppm} \mathrm{NAA}+100 \mathrm{ppm}$ putrescine) followed by treatments $\mathrm{T}_{18}$ (50 ppm NAA + 75 ppm putrescine), $\mathrm{T}_{17}$ (50 ppm $\mathrm{NAA}+50 \mathrm{ppm}$ putrescine), $\mathrm{T}_{16}(50 \mathrm{ppm}$ NAA + 25 ppm putrescine), T9 (50 ppm NAA), $\mathrm{T}_{5}$ (100 ppm putrescine), T13 (25 ppm NAA + 100 ppm putrescine) and $\mathrm{T}_{12}$ (25 ppm NAA + 75 ppm putrescine) in a descending manner when compared with treatment $\mathrm{T}_{1}$ (control) and other remaining treatments under study. From this data it is observed that leaf nitrogen content was increased up to 65 DAS and reduced thereafter at 85 DAS. The decrease in nitrogen content might be due to fact that younger leaves and developing organs, such as seed act as strong sink demand and may draw heavily nitrogen from older leaves (Gardner et al., 1988). The results are also in conformity with the findings of Amin et al. (2013). Putrescine or IBA enhances enzymatic activity and translocation processes from leaves to grains, linking or converting to other plant metabolites. Similarly, Kapase et al. (2014) carried out the field experiment to study the effect of humic acid through vermicompost wash and NAA and reported that foliar spray of 50 ppm NAA + 400 ppm HA through VCW followed by 50 ppm NAA and 300 ppm HA through VCW significantly enhanced leaf $\mathrm{N}$ content in chickpea.

\section{Leaf phosphorus content}

Phosphorus is an important constituent of protoplasm and nucleic acid and protein also, it is essential for the formation of seed. Data pertaining to phosphorus content in leaves were estimated at four stages of observations i.e. 25, 45,65 and 85 DAS. Phosphorus has been recognized as an important environmental factor limiting crop growth and production. Significant results were recorded at all the stages of observations viz., 45, 65 and 85 DAS except 25 DAS. Data are presented in table 1. At 45 DAS significantly maximum leaf phosphorus content was recorded in treatment $\mathrm{T}_{19}$ (50 ppm NAA + 100 ppm putrescine) followed by treatments $\mathrm{T}_{18}(50 \mathrm{ppm} \mathrm{NAA}+75 \mathrm{ppm}$ putrescine), $\mathrm{T}_{17}(50 \mathrm{ppm} \mathrm{NAA}+50 \mathrm{ppm}$ putrescine), $\mathrm{T}_{16}(50 \mathrm{ppm} \mathrm{NAA}+25 \mathrm{ppm}$ putrescine), $\mathrm{T}_{9}(50 \mathrm{ppm} \mathrm{NAA}), \mathrm{T}_{5}$ (100 ppm putrescine), $\mathrm{T}_{13}(25 \mathrm{ppm} \mathrm{NAA}+100 \mathrm{ppm}$ putrescine), $\mathrm{T}_{12}$ (25 ppm NAA + $75 \mathrm{ppm}$ putrescine), $\mathrm{T}_{11}$ (25 ppm NAA $+50 \mathrm{ppm}$ putrescine), $\mathrm{T}_{10}(25 \mathrm{ppm} \mathrm{NAA}+25 \mathrm{ppm}$ putrescine), $\mathrm{T}_{14}(25 \mathrm{ppm} \mathrm{NAA}+125 \mathrm{ppm}$ putrescine) and $\mathrm{T}_{15}(25 \mathrm{ppm}$ NAA $+150 \mathrm{ppm}$ putrescine) when compared with control and rest of the treatments under study. At 65 DAS significantly maximum leaf phosphorus content was recorded in treatment $\mathrm{T}_{19}(50 \mathrm{ppm} \mathrm{NAA}+100 \mathrm{ppm}$ putrescine) followed by treatments $\mathrm{T}_{18}$ (50 ppm NAA + 75 ppm putrescine), $\mathrm{T}_{17}$ (50 ppm $\mathrm{NAA}+50 \mathrm{ppm}$ putrescine), $\mathrm{T}_{16}(50 \mathrm{ppm}$ NAA + 25 ppm putrescine), $\mathrm{T}_{9}$ (50 ppm NAA), $\mathrm{T}_{5}$ (100 ppm putrescine), $\mathrm{T}_{13}$ (25 ppm NAA + 100 ppm putrescine), $\mathrm{T}_{12}$ (25 ppm NAA +75 ppm putrescine), $\mathrm{T}_{11}(25 \mathrm{ppm} \mathrm{NAA}+50 \mathrm{ppm}$ putrescine) and $\mathrm{T}_{10}(25 \mathrm{ppm} \mathrm{NAA}+25 \mathrm{ppm}$ putrescine) in a descending manner when compared with control and rest of the treatments under study. At 85 DAS significantly maximum leaf phosphorus content was recorded in treatment $\mathrm{T}_{19}$ (50 ppm NAA + 100 ppm putrescine) followed by treatments $\mathrm{T}_{18}(50 \mathrm{ppm} \mathrm{NAA}+75 \mathrm{ppm}$ putrescine), $\mathrm{T}_{17}(50 \mathrm{ppm} \mathrm{NAA}+50 \mathrm{ppm}$ putrescine), $\mathrm{T}_{16}$ (50 ppm NAA + $25 \mathrm{ppm}$ putrescine), T9 (50 ppm NAA), T5 (100 ppm putrescine), $\mathrm{T}_{13}$ (25 ppm NAA + $100 \mathrm{ppm}$ putrescine), $\mathrm{T}_{12}$ (25 ppm NAA + $75 \mathrm{ppm}$ putrescine), $\mathrm{T}_{11}$ (25 ppm NAA $+50 \mathrm{ppm}$ putrescine), $\mathrm{T}_{10}(25 \mathrm{ppm} \mathrm{NAA}+25 \mathrm{ppm}$ putrescine), $\mathrm{T}_{14}$ (25 ppm NAA + $125 \mathrm{ppm}$ putrescine), $\mathrm{T}_{15}(25 \mathrm{ppm} \mathrm{NAA}+150 \mathrm{ppm}$ putrescine) and $\mathrm{T}_{20}(50 \mathrm{ppm} \mathrm{NAA}+125 \mathrm{ppm}$ putrescine) in a descending manner when compared with control $\left(\mathrm{T}_{1}\right)$ and rest of the treatments. The inference drawn from the 
data, it is clear that leaf phosphorus content was gradually increased upto 65 DAS and reduced thereafter at 85 DAS. These results are confirmed by Amin et al. (2013), also tested two plant growth regulators viz., putrescine and Indole-3-butyric acid (IBA) @ 25, 50 and $100 \mathrm{mg} \mathrm{1}^{-1}$, applied either alone or in combinations. Spraying of putrescine and IBA@100 mg 1-1 significantly enhanced phosphorus content of chickpea (Cicer arietinum L.). Singh et al. (2015) also showed that foliar application of $50 \mathrm{ppm}$ NAA significantly increased $P$ concentration in seed and straw in fenugreek. Similarly phosphorus uptake were also found significantly enhanced by the application of NAA 50 ppm over control.

\section{Leaf potassium content}

Potassium is an essential macronutrient for plants involved in many physiological processes. It is important for crop yield as well as for the quality of edible parts of crops. Although $\mathrm{K}$ is not assimilated into organic matter, $\mathrm{K}$ deficiency has a strong impact on plant metabolism. Plant responses to low $\mathrm{K}$ involve changes in the concentrations of many metabolites as well as alteration in the transcriptional levels of many genes and in the activity of many enzymes. Data pertaining to potassium content in leaves were estimated at various stages of observations viz., 25, 45, 65 and 85 DAS. Significant results were recorded at all the stages of observations viz., 45, 65 and 85 DAS except 25 DAS. Data are presented in table 1 . At 45 DAS significantly more leaf potassium content was noticed in treatment $\mathrm{T}_{19}(50 \mathrm{ppm} \mathrm{NAA}+100 \mathrm{ppm}$ putrescine) followed by treatments $\mathrm{T}_{18}$ (50 ppm NAA +75 ppm putrescine), $\mathrm{T}_{17}(50 \mathrm{ppm}$ NAA +50 ppm putrescine), $\mathrm{T}_{16}(50 \mathrm{ppm}$ NAA + 25 ppm putrescine), T9 (50 ppm NAA), T5 (100 ppm putrescine), $\mathrm{T}_{13}$ (25 ppm NAA + 100 ppm putrescine) and $\mathrm{T}_{12}$ (25 ppm NAA + 75 ppm putrescine) when compared with control $\left(\mathrm{T}_{1}\right)$ and rest of the treatments under observations. At 65 DAS significantly maximum leaf potassium content was noticed in treatment $\mathrm{T}_{19}(50 \mathrm{ppm}$ NAA +100 ppm putrescine) followed by treatments $\mathrm{T}_{18}$ (50 ppm NAA +75 ppm putrescine), $\mathrm{T}_{17}$ (50 ppm NAA + 50 ppm putrescine), $\mathrm{T}_{16}$ (50 ppm $\mathrm{NAA}+25 \mathrm{ppm}$ putrescine), $\mathrm{T}_{9}(50 \mathrm{ppm}$ NAA) and $\mathrm{T}_{5} \quad(100 \mathrm{ppm}$ putrescine $)$ when compared with control and rest of the treatments under observations. At 85 DAS significantly maximum leaf potassium content was noted in treatment $\mathrm{T}_{19}(50 \mathrm{ppm}$ NAA + 100 ppm putrescine) followed by treatments $\mathrm{T}_{18}(50 \mathrm{ppm} \mathrm{NAA}+75 \mathrm{ppm}$ putrescine), $\mathrm{T}_{17}$ (50 ppm NAA $+50 \mathrm{ppm}$ putrescine), $\mathrm{T}_{16}$ (50 ppm NAA + $25 \mathrm{ppm}$ putrescine) and $\mathrm{T}_{9}(50 \mathrm{ppm}$ NAA) when compared with control and remaining treatments under observations. It is clear from the data, that leaf potassium content was decreased gradually in later stages of crop growth at 65 DAS and 85 DAS. It might be because of diversion of potassium towards developing parts i.e. seeds of the chickpea crop at advanced stage. Amin et al. (2013) have reported similar findings that application of putrescine or IBA increased enzymatic activity and translocation processes from leaves to seeds, linking or converting to other plant metabolites. Similarly, Kapase et al. (2014) carried out the field experiment to study the effect of humic acid through vermicompost wash and NAA and reported that foliar spray of 50 ppm NAA + 400 ppm HA through VCW followed by 50 ppm NAA and 300 ppm HA through VCW significantly enhanced leaf $\mathrm{K}$ content in chickpea.

\section{Leaf chlorophyll content}

Chlorophyll is a green pigment present in chloroplast of all green plant cells and tissues. These are essential photosynthetic pigments capable of absorbing light energy for the synthesis of carbohydrates. Chlorophyll content of the plant tissue represents the photosynthetic capacity of the plant. The greenness of the leaf is generally considered to be a parameter contributing to yielding ability of the cultivar. Leaves constitute most important aerial organ of the plants, playing a major role in the anabolic activities by means of the so called 'green pigments or chlorophyll' is the sole medium of the photosynthetic progress which in turn is the major synthesis pathway operatives in plants.

The treatment effects were found statistically significant at 45, 65 and 85 DAS stages of observations except 25 DAS. Data regarding leaf chlorophyll content in 
leaves of soybean are presented in table 1 . At 45 DAS chlorophyll content in leaves ranged from $1.37-2.04 \mathrm{mg} \mathrm{g}^{-1}$. Significantly highest chlorophyll was found in treatment $\mathrm{T}_{19}$ (50 ppm NAA + 100 ppm putrescine) followed by treatments $\mathrm{T}_{18}$ (50 ppm NAA + 75 ppm putrescine), $\mathrm{T}_{17}$ (50 ppm NAA +50 ppm putrescine), $\mathrm{T}_{16}(50 \mathrm{ppm}$ NAA $+25 \mathrm{ppm}$ putrescine), T9 (50 ppm NAA), T5 (100 ppm putrescine), $\mathrm{T}_{13}(25 \mathrm{ppm} \mathrm{NAA}+100 \mathrm{ppm}$ putrescine), $\mathrm{T}_{12}$ (25 ppm NAA $+75 \mathrm{ppm}$ putrescine), $\mathrm{T}_{11}$ (25 ppm NAA $+50 \mathrm{ppm}$ putrescine) and $\mathrm{T}_{10}(25 \mathrm{ppm} \mathrm{NAA}+25 \mathrm{ppm}$ putrescine) when compared with control $\left(\mathrm{T}_{1}\right)$. At 65 DAS chlorophyll content in leaves ranged from $1.45-2.24 \mathrm{mg} \mathrm{g}^{-1}$. Significantly highest chlorophyll content was found in treatment $\mathrm{T}_{19}(50 \mathrm{ppm} \mathrm{NAA}+100 \mathrm{ppm}$ putrescine) followed by treatments $\mathrm{T}_{18} \quad(50$ ppm NAA +75 ppm putrescine), $\mathrm{T}_{17}$ (50 ppm $\mathrm{NAA}+50 \mathrm{ppm}$ putrescine), $\mathrm{T}_{16}(50 \mathrm{ppm}$ NAA + 25 ppm putrescine), T9 (50 ppm NAA), T5 (100 ppm putrescine), T13 (25 ppm NAA + 100 ppm putrescine), $\mathrm{T}_{12}$ (25 ppm NAA +75 ppm putrescine) and $\mathrm{T}_{11}$ (25 ppm NAA +50 ppm putrescine) as compared to control $\left(\mathrm{T}_{1}\right)$ and remaining treatments. At 85 DAS chlorophyll content in leaves ranged from $1.25-2.15 \mathrm{mg} \mathrm{g} \mathrm{g}^{-1}$. Significantly highest chlorophyll content was found in treatment $\mathrm{T}_{19}$ (50 ppm NAA + $100 \mathrm{ppm}$ putrescine) followed by treatments $\mathrm{T}_{18}(50 \mathrm{ppm} \mathrm{NAA}+$ 75 ppm putrescine), $\mathrm{T}_{17}$ (50 ppm NAA +50 ppm putrescine), $\mathrm{T}_{16}(50 \mathrm{ppm} \mathrm{NAA}+25 \mathrm{ppm}$ putrescine), T9 (50 ppm NAA), T5 (100 ppm putrescine), $\mathrm{T}_{13}(25 \mathrm{ppm} \mathrm{NAA}+100 \mathrm{ppm}$ putrescine), $\mathrm{T}_{12}$ (25 ppm NAA $+75 \mathrm{ppm}$ putrescine) and $\mathrm{T}_{11}(25 \mathrm{ppm} \mathrm{NAA}+50 \mathrm{ppm}$ putrescine) as compared to control $\left(\mathrm{T}_{1}\right)$ and rest of treatments under study. It is obvious from the data that chlorophyll content in leaves was maximum at 45-65 DAS but thereafter, gradual decrease in chlorophyll content was noticed at 85 DAS. Nitrogen is a constituent element in chlorophyll which rapidly increases at vegetative stage, as the nitrogen reserves are in ample quantity at this stage. However, rate of nitrogen mobilization is more to the reproductive part than the rate of nitrogen uptake. Hence, increase in chlorophyll content during 4565 DAS might be due to increased uptake of $\mathrm{N}, \mathrm{P}, \mathrm{K}$ and other nutrients in early stage of plant growth. Putrescine or NAA treatments might retard chlorophyll destruction and increase their biosynthesis or stabilize the thylakoid membrane. Polyamines may retard senescence and chlorophyll loss by altering the stability and permeability of membranes and protecting chloroplast from senescing (Gonzalez-Aguilar et al., 1997). These might be the reasons for increase in leaf chlorophyll content by the application of putrescine and NAA. These findings are in line with that of Deotale et al. (2016) who tested different concentrations of Putrescine and IBA $(50,75,100,125$ and $150 \mathrm{ppm}$ each) with one control on chemical, biochemical, yield and yield contributing characters of soybean and reported that two foliar sprays of $100 \mathrm{ppm}$ Putrescine and 100 ppm IBA at two stages i.e. before flowering and 10 days after flowering were found to be most effective in enhancing $\mathrm{N}, \mathrm{P}, \mathrm{K}$ and chlorophyll content in leaves. Similarly, Kapase et al. (2014) carried out the field experiment to study the effect of humic acid through vermicompost wash and NAA and reported that foliar spray of 50 ppm NAA + 400 ppm HA through VCW followed by 50 ppm NAA and 300 ppm HA through VCW significantly enhanced leaf chlorophyll content in chickpea.

\section{Protein content in seed}

Although quality of crop products such as oil, protein and sucrose content and appearance is genetically controlled, the nutrition of plants can have considerable impact on the expression of quality. It is therefore, essential to judiciously take care on the nutrient supply at grain formation stage. Protein content of the seed is one of the considerable factors for seed quality determination also. The Table- 2 gives detail data on protein content. 
Table-2. Effect of putrescine and NAA on protein (\%), yield and yield contributing parameters of chickpea

\begin{tabular}{|c|c|c|c|c|c|}
\hline Treatments & $\begin{array}{c}\text { Seed } \\
\text { protein } \\
\text { content } \\
(\%)\end{array}$ & $\begin{array}{c}\text { No. of } \\
\text { pods } \\
\text { plant-1 }\end{array}$ & $\begin{array}{c}100 \\
\text { seed } \\
\text { weight } \\
\text { (g) }\end{array}$ & $\begin{array}{l}\text { Seed yield } \\
\mathrm{ha}^{-1}(\mathrm{q})\end{array}$ & B:C Ratio \\
\hline $\mathbf{T}_{1}$ (control) & 19.43 & 26.00 & 20.22 & 18.13 & 5.1 \\
\hline$T_{2}$ (25 ppm putrescine) & 19.53 & 29.20 & 20.36 & 18.81 & 4.5 \\
\hline $\mathrm{T}_{3}(50$ ppm putrescine ) & 20.00 & 33.60 & 21.36 & 19.93 & 4.1 \\
\hline $\mathrm{T}_{4}$ (75 ppm putrescine) & 20.48 & 34.40 & 21.76 & 20.07 & 3.7 \\
\hline$T_{5}(100$ ppm putrescine ) & 22.50 & 48.30 & 24.00 & 22.73 & 3.7 \\
\hline$T_{6}$ (125 ppm putrescine ) & 19.83 & 32.00 & 20.97 & 19.62 & 2.9 \\
\hline$T_{7}$ (150 ppm putrescine ) & 19.67 & 31.40 & 20.76 & 19.29 & 2.6 \\
\hline$T_{8}$ (25 ppm NAA) & 20.83 & 35.00 & 21.79 & 20.43 & 5.5 \\
\hline$T_{9}$ (50 ppm NAA) & 22.51 & 51.40 & 24.27 & 22.86 & 5.9 \\
\hline $\begin{array}{l}\mathrm{T}_{10}(25 \mathrm{ppm} \mathrm{NAA}+25 \mathrm{ppm} \\
\text { putrescine) }\end{array}$ & 21.80 & 39.20 & 23.05 & 21.69 & 5.0 \\
\hline $\begin{array}{l}T_{11}(25 \text { ppm NAA + } 50 \text { ppm } \\
\text { putrescine) }\end{array}$ & 22.00 & 40.40 & 23.22 & 21.97 & 4.4 \\
\hline $\begin{array}{l}T_{12}(25 \text { ppm NAA }+75 p p m \\
\text { putrescine) }\end{array}$ & 22.19 & 43.50 & 23.64 & 22.25 & 4.0 \\
\hline $\begin{array}{l}T_{13}(25 \text { ppm NAA + } 100 \text { ppm } \\
\text { putrescine) }\end{array}$ & 22.26 & 45.00 & 23.76 & 22.47 & 3.6 \\
\hline $\begin{array}{l}\mathrm{T}_{14}(25 \mathrm{ppm} \text { NAA }+125 \mathrm{ppm} \\
\text { putrescine })\end{array}$ & 21.62 & 38.60 & 22.90 & 21.28 & 3.1 \\
\hline $\begin{array}{l}T_{15}(25 \text { ppm NAA }+150 \text { ppm } \\
\text { putrescine) }\end{array}$ & 21.33 & 37.80 & 22.67 & 21.09 & 2.8 \\
\hline $\begin{array}{l}\mathrm{T}_{16}(50 \text { ppm NAA }+25 \text { ppm } \\
\text { putrescine ) }\end{array}$ & 23.00 & 52.00 & 24.40 & 23.11 & 5.1 \\
\hline $\begin{array}{l}T_{17}(50 \text { ppm NAA + } 50 \text { ppm } \\
\text { putrescine) }\end{array}$ & 23.10 & 54.00 & 24.78 & 23.44 & 4.2 \\
\hline $\begin{array}{l}\mathrm{T}_{18}(50 \text { ppm NAA }+75 \text { ppm } \\
\text { putrescine) }\end{array}$ & 23.42 & 54.60 & 25.19 & 23.91 & 4.1 \\
\hline $\begin{array}{l}T_{19}(50 \text { ppm NAA + } 100 \text { ppm } \\
\text { putrescine ) }\end{array}$ & 23.48 & 55.80 & 25.50 & 24.18 & 3.8 \\
\hline $\begin{array}{l}\mathrm{T}_{20}(50 \text { ppm NAA }+125 \text { ppm } \\
\text { putrescine ) }\end{array}$ & 21.20 & 36.20 & 22.58 & 20.96 & 3.0 \\
\hline $\begin{array}{l}\mathrm{T}_{21}(50 \text { ppm NAA }+150 \text { ppm } \\
\text { putrescine ) }\end{array}$ & 20.94 & 35.80 & 22.34 & 20.83 & 2.7 \\
\hline $\begin{array}{l}\mathrm{SE}(\mathrm{m}) \pm \\
\mathrm{CD} \text { at } 5 \%\end{array}$ & $\begin{array}{l}0.893 \\
2.533\end{array}$ & $\begin{array}{l}2.729 \\
7.799\end{array}$ & $\begin{array}{l}1.155 \\
3.301\end{array}$ & & - \\
\hline & & & & 3.533 & - \\
\hline
\end{tabular}

Data indicated that protein content was significantly increased in treatment $\mathrm{T}_{19}$ (50 ppm NAA + 100 ppm putrescine) followed by treatments $\mathrm{T}_{18}(50 \mathrm{ppm} \mathrm{NAA}+75 \mathrm{ppm}$ putrescine), $\mathrm{T}_{17}$ (50 ppm NAA $+50 \mathrm{ppm}$ putrescine), $\mathrm{T}_{16}$ (50 ppm NAA + $25 \mathrm{ppm}$ putrescine), T9 (50 ppm NAA), T5 (100 ppm putrescine), $\mathrm{T}_{13}$ (25 ppm NAA + $100 \mathrm{ppm}$ putrescine) when compared with control $\left(\mathrm{T}_{1}\right)$ and rest of the treatments in a descending manner. Chickpea plants have high $\mathrm{N}$ requirement for seed production. Major part of $\mathrm{N}$ is accumulated in the seed during pod filling stage. Nitrogen is key component in mineral fertilizers and has more influence on plant growth, appearance and fruit 
production / quality than any other element. It affects the absorption and distribution of other essential elements. Foliar application of growth promoters Putrescine and NAA increases the uptake and availability of nutrients and its further assimilation for biosynthesis of protein. Hence, increase in nitrogen content ultimately resulted in the increase in protein content in seeds of chickpea in the present investigation. Foliar application of putrescine and IBA increased seed protein content in the present investigation might be due to more enzymatic activity and translocation processes from leaves to seeds and linking or conversion of other plant metabolites (Amin, 2013). The results are supported by El-Bassiouny (2004) who demonstrated that, Putrescine treatments significantly increased protein percentage of the yielded pea seeds while carbohydrate percentage was not affected as compared to control. She attributed this increase to the translocation of amino acids from shoots to seeds and the increase in protein synthesis in pea shoots. Medhi et al. (2014) reported that application of growth regulators (IAA 25 ppm, NAA $50 \mathrm{ppm}$, ascorbic acid $25 \mathrm{ppm}$, ethrel $250 \mathrm{ppm}$ and gibberellic acid $30 \mathrm{ppm}$ ) and phosphorus levels $(20,40$ and $60 \mathrm{~kg}$ ha $\left.{ }^{1}\right)$ significantly improved nutritional parameters of seed viz., total solubl starch, protein and free amino acid content.

\section{Yield and yield contributing parameters}

Yield is complex character determined by several traits internal plant processes and environmental factors. Seed yield, and its related parameters in chickpea were influenced by the application of growth regulator which have different influence on the allocation of assimilates between vegetative and reproductive organs. In general crop yield depends on the accumulation of photo-assimilates during the growing period and the way, they are partitioned between desired storage organ of plant. In present study, data revealed that the application of plant growth regulators significantly increased, number of pods plant $^{-1}, 100$ seed weight and finally seed yield determining components in chickpea.

\section{Number of pods plant-1}

It is known that number of pods plant ${ }^{-1}$ is an important yield determinant. Data regarding number of pods plant ${ }^{-1}$ was recorded at harvesting stage and are tabulated in table 2. Data pertaining to number of pods plant ${ }^{-1}$ was found significantly superior due to various treatments of the putrescine and NAA. The number of pods plant ${ }^{-1}$ recorded were 26.00 and 55.80 in $\mathrm{T}_{1}$ (control) and $\mathrm{T}_{19}(50 \mathrm{ppm}$ $\mathrm{NAA}+100 \mathrm{ppm}$ putrescine) respectively, followed by treatments $\mathrm{T}_{18}(50 \mathrm{ppm}$ NAA + $75 \mathrm{ppm}$ putrescine), $\mathrm{T}_{17}$ (50 ppm NAA +50 ppm putrescine), $\mathrm{T}_{16}(50 \mathrm{ppm} \mathrm{NAA}+25 \mathrm{ppm}$ putrescine), $\mathrm{T}_{9}$ (50 ppm NAA) and $\mathrm{T}_{5}(100$ ppm putrescine) in a descending manner when compared with treatment $\mathrm{T}_{1}$ (control) and rest of the treatments under study. Similarly, treatments $\mathrm{T}_{13}(25$ ppm NAA +100 ppm putrescine), $\mathrm{T}_{12}$ (25 ppm NAA $+75 \mathrm{ppm}$ putrescine), $\mathrm{T}_{11}$ (25 ppm NAA $+50 \mathrm{ppm}$ putrescine), $\mathrm{T}_{10}(25 \mathrm{ppm} \mathrm{NAA}+25 \mathrm{ppm}$ putrescine), $\mathrm{T}_{14}(25 \mathrm{ppm} \mathrm{NAA}+125 \mathrm{ppm}$ putrescine), $\mathrm{T}_{15}(25 \mathrm{ppm} \mathrm{NAA}+150 \mathrm{ppm}$ putrescine), $\mathrm{T}_{20}(50 \mathrm{ppm} \mathrm{NAA}+125 \mathrm{ppm}$ putrescine), $\mathrm{T}_{21}$ (50 ppm NAA + $150 \mathrm{ppm}$ putrescine), T8 (25 ppm NAA), $\mathrm{T}_{4}$ (75 ppm putrescine) were also found significantly superior over control $\left(\mathrm{T}_{1}\right)$. These findings are inline with that of Medhi et al. (2014) who reported that foliar application of NAA 50 ppm recorded the highest yield of green gram i.e., $44 \%$ increased over control due to highest number of pods. Similar results were also obtained by Amin et al. (2013) who tried two plant growth regulators putrescine and Indole-3-butyric acid (IBA) @ 25, 50 and $100 \mathrm{mg} \mathrm{l}^{-1}$ applied either alone or in combinations on chickpea. Spraying of putrescine and IBA @ 100 mg 1-1 significantly increased number of pods.

\section{0 seeds weight}

The development of grains in pods depends on supply of photosynthets to developing grains. The 100 seed weight is thus a function of dry matter production and translocation efficiency of the plant. Data regarding 100 seed weight showed significant variation and are given in table 2. Variation in data of 100 seed weight owing to different concentrations of putrescine and NAA was significant. Treatment $\mathrm{T}_{19}(50 \mathrm{ppm}$ NAA +100 ppm 
putrescine) gave significantly maximum 100 seed weight (i.e. $25.5 \mathrm{~g})$ followed by treatments $\mathrm{T}_{18}(50 \mathrm{ppm} \mathrm{NAA}+75 \mathrm{ppm}$ putrescine), $\mathrm{T}_{17}(50 \mathrm{ppm} \mathrm{NAA}+50 \mathrm{ppm}$ putrescine), $\mathrm{T}_{16}$ (50 ppm NAA + $25 \mathrm{ppm}$ putrescine), T9 (50 ppm NAA), T5 (100 ppm putrescine), $\mathrm{T}_{13}(25 \mathrm{ppm} \mathrm{NAA}+100 \mathrm{ppm}$ putrescine), $\mathrm{T}_{12}$ (25 ppm NAA $+75 \mathrm{ppm}$ putrescine) when compared with remaining treatments and control $\left(\mathrm{T}_{1}\right)$. These results are in match with that of Medhi et al. (2014), who reported that foliar application of NAA 50 ppm recorded the highest yield of green gram i.e., 44\% increased over control due to highest number of 1000 seed weight (g). Similarly, Wagh (2015) evaluated the effect of different concentrations of putrescine and IBA ( 0, 50, 75, 100, 125 and $150 \mathrm{ppm}$ ) on soybean. Data showed that 2 foliar sprays of putrescine and IBA @ 100 ppm significantly enhanced 100 seed weight (g).

\section{Seed yield ha-1 (q)}

Data regarding seed yield ha-1 are given in table 2. Seed yield is a complex physiological character which is the sum total of all metabolic activities taking place in plant body. Seed yield and its related parameters were influenced by the application of different growth regulators in chickpea which indicated that these chemicals have differential influence on the allocation of assimilates between vegetative and reproductive organs. In general, crop yield depends on the accumulation of photoassimilates during the growing period and the way they are partitioned between desired storage organs of plant. In the present study, it is revealed that the application of PGRs significantly increased the number of pods, 100-seed weight and finally seed yield ha-1 which are the most important yield determining components in chickpea. Significantly maximum seed yield $\mathrm{ha}^{-1}$ was recorded in treatment $\mathrm{T}_{19}(50 \mathrm{ppm}$ $\mathrm{NAA}+100$ ppm putrescine) followed by treatments $\mathrm{T}_{18}(50 \mathrm{ppm} \mathrm{NAA}+75 \mathrm{ppm}$ putrescine), $\mathrm{T}_{17}$ (50 ppm NAA $+50 \mathrm{ppm}$ putrescine), $\mathrm{T}_{16}$ (50 ppm NAA $+25 \mathrm{ppm}$ putrescine), $\mathrm{T}_{9}$ (50 ppm NAA), $\mathrm{T}_{5}(100 \mathrm{ppm}$ putrescine), $\mathrm{T}_{13}$ (25 ppm NAA + 100 ppm putrescine), $\mathrm{T}_{12}$ (25 ppm NAA $+75 \mathrm{ppm}$ putrescine), $\mathrm{T}_{11}$ (25 ppm NAA $+50 \mathrm{ppm}$ putrescine) and $\mathrm{T}_{10}(25 \mathrm{ppm}$ NAA $+25 \mathrm{ppm}$ putrescine) over control ( $\left.\mathrm{T}_{1}\right)$. The increase in the yield recorded in this investigation could be a reflection of the effect of growth regulators Putrescine and NAA on growth and development. It might also be due to marked increase in plant height, leaf area and dry weight which gave a chance to the plant to carry more seeds and marked increase in the photosynthetic pigments content which could lead to increase in photosynthesis, resulting in greater transfer of assimilates to the seeds and causing increase in their weight. The promotive effects of Putrescine and NAA on the harvestable yields of chickpea indicated that the strengths (defined as sink size / sink activity) of reproductive parts are greatly increased, when compared with control. The above finding was in corroboration with the findings of Amin et al. (2013), who studied the effect of two plant growth regulators putrescine and Indole-3-butyric acid (IBA) @ 25, 50 and 100 mg 1-1 applied either alone or in combinations. Spraying of putrescine and IBA @ $100 \quad \mathrm{mg}^{1-1}$ significantly increased number of pods, seed yield, straw and biological yield feed ${ }^{-1}$ of chickpea (Cicer arietinum). Similarly, Medhi et al. (2014) reported that foliar application of NAA $50 \mathrm{ppm}$ recorded the highest yield of green gram i.e., 44\% increased over control due to highest number of pod, number of seed, 1000 seed weight. Wagh (2015) evaluated the effect of different concentrations of putrescine and IBA ( 0 , $50,75,100,125$ and $150 \mathrm{ppm}$ ) on soybean. Data showed that 2 foliar sprays of putrescine and IBA@100 ppm significantly enhanced 100 seed weight, number of pods plant $^{-1}$ and seed yield over control. Kapase et al. (2014) studied the effect of humic acid through vermicompost wash and NAA on chickpea and reported that foliar spray of 50 ppm NAA + 400 ppm HA through VCW followed by 50 ppm NAA and 300 ppm HA through VCW significantly increased seed yield ha ${ }^{1}$.

From overall results, it can be stated that foliar application of growth regulators such as putrescine and NAA with different concentrations improved the chemical, biochemical, yield and yield contributing 
parameters might have helped in attaining better seed yield in the present investigation. The highest per cent increased in yield over control was observed in foliar application of 50 ppm NAA + 100 ppm putrescine $\left(\mathrm{T}_{19}\right)$ i.e. $33.37 \%$ over control $\left(\mathrm{T}_{1}\right)$. But, considering the $\mathrm{B}$ : $\mathrm{C}$ ratio foliar application of 50 ppm NAA was found most effective treatment having $B$ : $C$ ratio of 5.9 as compared to 5.1 in control. Finally on the basis of $\mathrm{B}$ : $\mathrm{C}$ ratio it is inferred that, spraying plants at vegetative stage (30-35 DAS) with 50 ppm NAA could be considered as the most suitable time and most suitable concentration to expect promising improvement regarding the growth parameters, physiological characters and yield quantity and quality of chickpea.

\section{References:}

Amin, A.A., F.A. Gharib, H.F. Abouziena and Mona G. Dawood, 2013. Role of indole3-butyric acid or/and putrescine in improving productivity of Chickpea (Cicer arientinum L.) Plants.Pakistan J. Biol. Sci. 16: 1894-1903.

Biasi, R., G.Costa and N. Bagni,1991. Polyamine metabolism as related to fruit set and growth.Pl. Physiol. Biochem.29:497506.

Bueno,M. and A.Matilla,1992. Effect of spermine and abscisic acid on mitotic divisions in isolated embryonic axes of chickpea seeds.Cytobiology, 71:151-155.

Deotale, R. D., Y. A. Wagh, S. R. Patil and V. B. Kalamkar, 2016. Influence of putrescine and Indol-3 butyric acid on chemical and biochemical parameters and yield of soybean. International Journal of Current research. 8 (3): 27248-27255.

El-Bassiouny, H.M.S. 2004. Increasing thermotolerance of Pisum sativum L. Plants through application of putrescine and stigmasterol. Egypt. J. Biotech. 18: 93-118.

Gardner, F. P., R. B. Pearce and R. L. Mitchell. 1988. Transport and partitioning. In physiology of crop plants. 2nd Ed. Scientific publishers, Jodhpur. pp.58-95.

Gonzalez-Aguilar, G.A., L. Zacarias, M. Mulas and M.T. Lafuente, 1997. Temperature and duration of water dips influence chilling injury, decay and polyamine content in Fortune mandarins. Post harvest Biol. Technol. 12: 61-69.

Jain, V. K. 2010. Mineral nutrition of plants.In Fundamentals of plant physiology. S. Chand and company LTD. New Delhi, Ed. 12 $2^{\text {th }}$ pp.101-104.
Kapase, P. V. 2014. Effect of foliar sprays of humic acid through vermicompost wash with NAA on growth and yield of chickpea. J. Soils and Crops. 24(1): 107-114

Khanzada, A., M. Jamal, M.S. Baloch and K. Nawab, 2002. Effect of naphthalein acetic acid (NAA) on yield of soybean. Pak. J. Biol. Sci. 3 (5): 856-857.

Medhi, A.K., S. Dhar, A. Roy, 2014. Effect of different growth regulators and phosphorous levels on nodulation, yield and quality components in green gram. Ind. Plant Physiol. 19: 74-78.

Panse, V. G. and P. V. Sukhatme, 1954. Statistical methods for agriculture workers. ICAR , New Delhi 2nd pp. 63-66.

Sharma, R., G. Singh and K. Sharma, 1989. Effect of triacontanol, mixatol and NAA on yield and it's components in mung bean. Indian J. agric. 3(1): 59-60.

Singh, A., S.P. Singh, A.K. Mahawar and T.V. Yadav, 2015. Influence of different plant growth regulators and zink levels on growth and quality aspects of fenugreek (Trigonellafoenum-graecum L.) under semiarid conditions. J. Spices and Aromatic Crops. 24: 149-152.

Singh, G.S. and B. Sharma. 1982. Effect of plant growth regulators on groundnut productivity. India J. of Ecol., 9 (2): 281 285.

Solamani, A., C. Sivakumar, S. Anbumani, T. Suresh and K. Arumugam, 2001. Role of plant growth regulators on rice production. A review. Agric. Rev. 23: 33-40.

Suty, L. 1984. Growth regulator and potential of faba bean. Cultivar. 171: 71-73. Upadhyay, R.G., B.B. Singh and D.N. Yadav. 1993. Effect of bioregulators on biochemical constituent and yield of chickpea (Cicer arietinum L.). Indian J. Plant Physiol. 36(3): 195 - 196.

Wagh, Y. A. 2015. Influence of putrescine and indol -3 butyric acid on growth and productivity of soybean. M.Sc. (Agri.) thesis (unpublished) submitted to Dr. P. D. K. V. Akola. 